Ethos (Jurnal Penelitian dan Pengabdian Masyarakat): 175-181

\title{
Meningkatkan Kompetensi Guru SMA Dan Sederajat Melalui Pelatihan PEMBELAJARAN BERBASIS TIK
}

\author{
THE IMPROVING COMPETENCE OF TEACHER IN High SCHOOL AND EQUIVALENT THROUGH TRAINING OF \\ ICT-BASED LEARNING
}

\author{
${ }^{1}$ M. Yusuf Fajar, ${ }^{2}$ Onoy Rohaeni, ${ }^{3}$ Yurika Permanasari, ${ }^{4}$ Anneke Iswani A, ${ }^{5}$ Kiki Mulkiya \\ ${ }^{1,2,3}$ Program Studi Matematika Fakultas MIPA Universitas Islam Bandung ${ }^{4}$ Program Studi Statistika \\ Fakultas MIPA Universitas Islam Bandung ${ }^{5}$ Program Studi Farmasi Fakultas MIPA Universitas Islam \\ Bandung \\ Email: '
}

\begin{abstract}
The low quality of teachers in Indonesia visibly from the results of teacher competency test in 2012, the average score of a high school teacher in West Java province is only 55.35. Imam Abdul Syukur research results (2014), showed that: $62.15 \%$ teachers rarely use Information and Communication Technology (ICT) in learning process and $34.95 \%$ of the teachers did not mastering the ICT. These conditions are not different from the situation of teachers in the district Cileunyi Bandung regency, according to the Principal of SMAN 1 Cileunyi Bandung, only $20 \%$ of teachers who use ICT in learning process. To overcome these problems, conducted "Improving High School and equivalent Teacher's Competence Through the Training of ICT-Based Learning in the District of Bandung Regency Cileunyi" training. During the training the participants were given materials such as Microsoft Excel software utilization in terms of the introduction of general function purpose, input the data into a worksheet, the Mathematics and Statistics formula, function of arguments and logic, application data charts, mail merge, and presentation techniques using Prezi software. To optimize the training activities, the training is followed by the mentoring of participants. The achieved result from the training is the participants have increased their knowledge of Microsoft Excel and learning process using Prezi software. After assisting, the trainees can make the process of evaluation of student learning using Microsoft Excel. But for the learning process, only $50 \%$ of participants who succeeded in making teaching materials using Prezi software. This is due to internet connection and infrastructure in schools that were inadequate.

Keywords: learning, information communications technology, Microsoft Excel, Prezi.
\end{abstract}

\begin{abstract}
Abstrak. Rendahnya kualitas guru di Indonesia nampak dari hasil uji kompetensi guru pada tahun 2012, nilai rata-rata guru SMA di Provinsi Jawa Barat hanya 55,35. Hasil penelitian Imam Abdul Syukur (2014), menunjukkan bahwa: 62,15\% guru jarang menggunakan Teknologi Informasi dan Komunikasi (TIK) dalam pembelajaran dan 34,95\% guru kurang menguasai TIK. Kondisi seperti ini tidak berbeda jauh dengan keadaan guru-guru di Kecamatan Cileunyi Kabupaten Bandung, menurut Kepala Sekolah SMAN 1 Cileunyi Bandung, baru 20\% guru yang menggunakan TIK dalam pembelajaran. Untuk mengatasi permasalahan tersebut, dilakukan kegiatan pelatihan "Meningkatkan Kompetensi Guru SMA dan Sederajat Melalui Pelatihan Pembelajaran Berbasis TIK di Kecamatan Cileunyi Kabupaten Bandung”. Pada pelatihan peserta diberikan materi berupa pemanfaatan software Microsoft Excel dalam hal pengenalan fungi-fungsi umum, input data ke dalam lembar kerja, rumus Matematika dan Statistika, fungsi
\end{abstract}


argumen dan logika, aplikasi grafik data, mail merge, dan teknik presentasi menggunakan software Prezi. Untuk mengoptimalkan kegiatan pelatihan, dilanjutkan dengan melakukan pendampingan kepada peserta.Hasil yang dicapai dari kegiatan pelatihan adalah peserta mengalami peningkatan pengetahuan tentang Microsoft Excel dan pembelajaran yang menggunakan software Prezi. Setelah dilakukan pendampingan semua peserta pelatihan dapat melakukan proses evaluasi hasil belajar siswa menggunakan Microsoft Excel. Namun untuk proses pembelajaran, hanya 50\% peserta yang berhasil membuat bahan ajar menggunakan software Prezi. Hal ini disebabkan kendala koneksi internet, dan sarana prasarana di sekolah yang kurang memadai. .

Kata kunci : pembelajaran, teknologi komunikasi informasi, Microsoft Excel, Prezi.

\section{Pendahuluan}

Rendahnya kualitas guru di Indonesia nampak dari hasil uji kompetensi guru secara nasional yang dilakukan pada tahun 2012. Berdasarkan hasil uji kompetensi guru tersebut, nilai rata-rata guru SMA di Provinsi Jawa Barat hanya 55,35 (Sumber : Konferensi Pers Menteri Pendidikan dan Kebudayaan, 16 Maret 2012). Sedangkan nilai kompetensi guru minimal mencapai 70 dari skor maksimal 100.

Hasil penelitian yang dilakukan oleh Imam Abdul Syukur (2014), menunjukkan bahwa : 62,15\% guru jarang menggunakan Teknologi Informasi dan Komunikasi (TIK) dalam pembelajaran, 34,95\% guru kurang menguasai Teknologi Informasi dan Komunikasi, dan $10,03 \%$ sarana dan prasarana yang ada kurang mendukung dalam pembelajaran.

Kondisi seperti ini tidak berbeda jauh dengan keadaan guru-guru di Kecamatan Cileunyi Kabupaten Bandung. Dari segi sarana dan prasarana sudah tersedia komputer di sekolah masing masing, namun guru guru kurang mampu untuk menggunakan baik dalam pembelajaran, maupun penilaian yang berbasis TIK.

Menurut Kepala Sekolah dan guru SMAN 1 Cileunyi Kabupaten Bandung, baru $20 \%$ guru-guru yang menggunakan pembelajaran berbasis TIK. Apalagi saat ini sesuai dengan Peraturan Menteri Pendidikan dan Kebudayaan Nomor 53 tentang penilaian, yang mewajibkan guru dalam melakukan penilaian berdasarkan penilaian sikap, pengetahuan, dan keterampilan. Untuk pengolahan hasil penilaian, pemanfaatan dan tindak lanjut hasil penilaian, membutuhkan keterampilan guru untuk menggunakan komputer dengan program Microsoft Excel dan Microsoft Word. Setiap guru Mata Pelajaran memberikan penilaian untuk setiap siswa, kemudian dikumpulkan di bagian Kurikulum. Selanjutnya dari bagian kurikulum di sekolah, nilai setiap mata pelajaran diserahkan ke masing-masing guru wali untuk diolah menjadi nilai raport setiap siswa. Pekerjaan guru wali mengolah data nilai memerlukan ketrampilan komputer dengan mengambil data dari file Microsoft Excel masing-masing nilai mata pelajaran untuk digabungkan (mail merge) ke file raport dalam bentuk file Microsoft Word.

Berdasarkan kondisi inilah dimana komputer sudah tersedia di setiap sekolah, software mudah diperoleh, namun sumber daya manusia dalam hal ini guru kurang mampu dalam menggunakannya baik untuk proses pembelajaran maupun untuk proses evaluasi pembelajaran, maka perlu dilakukan upaya untuk meningkatkan kompetensi guru melalui pelatihan Pembelajaran Berbasis TIK di Kecamatan Cileunyi Kabupaten Bandung. 


\section{Metode Pelaksanaan}

Kegiatan pelatihan dalam rangka Pengabdian Kepada Masyarakat (PKM) ini dilaksanakan melalui pelaksanaan pelatihan dimana di awal kegiatan, para peserta mendapatkan pemaparan teori kemudian terlibat mempraktekkan secara langsung penggunaan beberapa software komputer dengan menggunakan data yang dimiliki oleh masing-masing guru. Pelatihan diberikan untuk meningkatkan pengetahuan dan ketrampilan kepada guru-guru tentang pembelajaran berbasis TIK, khususnya dalam evaluasi hasil pembelajaran menggunakan Microsoft Excel dan dalam proses pembelajaran menggunakan software Prezi. Kemudian dilakukan pendampingan untuk mengoptimalkan dalam pembelajaran berbasis TIK sehingga guru-guru dapat mengimplementasikan kegiatan pembelajaran berbasis TIK.

Pada pelatihan peserta diberikan materi berupa teori 30\% dan praktek $70 \%$ yang disampaikan secara bersamaan. Adapun materi yang diberikan berupa materi pemanfaatan software Microsoft Excel dalam hal pengenalan Microsoft Excel, pengenalan fungi-fungsi umum dalam Microsoft Excel, input data ke dalam lembar kerja (worksheet), menuliskan dan memanfaatkan fungsi rumus Matematika dan Statistika, menggunakan fungsi argumen dan logika, aplikasi grafik data. Setelah peserta memahami penggunaan Microsoft Excel, peserta membuat latihan evaluasi hasil pembelajaran siswa menggunakan Microsoft Excel dengan data yang dimiliki masingmasing guru. Setelah peserta melakukan evaluasi hasil belajar siswa, kemudian dilanjutkan dengat materi mail merge, dan memindahkan tampilan data dari Microsoft Excel ke dalam file Microsoft Word. Selain itu juga, para peserta mendapatkan materi pelatihan mengenai teknik presentasi menggunakan software Prezi.

Untuk mengoptimalkan hasil dari kegiatan pelatihan, dilanjutkan dengan melakukan pendampingan kepada peserta.

\section{Realisasi Pelaksanaan}

Kegiatan Pelatihan Pembelajaran TIK dalam rangka Pengabdian Kepada Masyarakat (PKM) ini telah dilaksanakan pada tanggal 27 dan 28 Februari 2016, mulai pukul 08.30 - 15.00 WIB, bertempat di laboratorium komputer SMA Negeri 1 Cileunyi, Jalan Pendidikan No. 6, Cileunyi Kabupaten Bandung.

Peserta kegiatan terdiri dari para guru SMA dan sederajat di lingkungan Kecamatan Cileunyi Kabupaten Bandung. Para peserta mendaftarkan diri di bawah koordinasi dengan pihak SMA Negeri 1 Cileunyi. Penyebaran informasi kegiatan dilakukan melalui pengiriman surat dan brosur ke beberapa SMA dan sederajat di Kecamatan Cileunyi Kabupaten Bandung. Jumlah peserta yang hadir sebanyak 38 orang peserta dengan rincian sebagai berikut: 33 orang peserta berasal dari SMA Negeri 1 Cileunyi, 2 orang peserta berasal dari SMA Karya Budi Cileunyi, dan 3 orang peserta berasal dari MA Al-Jawami Cileunyi.

Para peserta mendapatkan fasilitas berupa penyampaian materi dalam bentuk visualisasi dan simulasi multimedia, pelatihan kit dan sertifikat. Sebelum mendapatkan materi, kepada para peserta diberikan pre-test selama kurang lebih 30 menit.

Pada hari pertama, 27 Februari 2016, materi yang diberikan berupa Pengenalan Microsoft Excel secara umum, pengenalan fungsi-fungsi toolbar pada Microsoft Excel, cara input data, edit data dan content pada tabel, penggunaan jendela rumus, fungsi matematika, fungsi statistika, dan pengolahan data ke dalam grafik atau chart.

Pada hari kedua, yaitu 28 Februari 2016, materi yang diberikan berupa fungsi logika, fungsi teks, pengenalan fungsi mail merge dan teknik presentasi menggunakan 
software Prezi. Mail merge adalah salah satu fasilitas dalam Microsoft Word yang digunakan membuat dokumen dengan template yang sama. Dalam hal ini, para guru dapat memanfaatkan fungsi mail merge dalam pengisian data siswa dalam raport sehingga tidak perlu dilakukan berulang-ulang. Sedangkan software Prezi, merupakan sebuah software untuk presentasi berbasis internet. Dengan menggunakan software Prezi ini, diharapkan penyampaian materi oleh guru dapat lebih meningkatkan minat belajar para siswa.

\section{Hasil yang dicapai}

Yang mengikuti Pretest ada 38 orang dengan materi pengetahuan tentang Microsoft Excel, 3 tipe data dalam Microsoft Exel, fungsi pada Microsoft Excel, 5 formula yang difasilitasi oleh Microsoft Exel, fungsi mailing pada Microsoft Word, langkah-langkah yang dilakukan dalam penggunaan Mailings, dan software Prezi. Nilai yang diperoleh oleh peserta pelatihan setelah diolah menggunakan SPSS diperoleh :

Tabel 1 . Nilai Pretest Peserta Pelatihan

\begin{tabular}{|l|r|r|}
\hline \multicolumn{2}{|c|}{} & \multicolumn{2}{|c|}{ Pretest } \\
\hline $\mathrm{N}$ & Valid & 38 \\
\cline { 2 - 3 } & Missing & 0 \\
\hline Mean & 35.8332 \\
\hline Median & 33.3300 \\
\hline Mode & 33.33 \\
\hline Std. Deviation & 12.79168 \\
\hline Variance & 163.627 \\
\hline Range & 58.33 \\
\hline Minimum & 16.67 \\
\hline Maximum & 75.00 \\
\hline
\end{tabular}

Dari Tabel 1 terlihat ada nilai terkecil yang diperoleh oleh peserta adalah 16.67 dan tertinggi 75, sehingga jarak (range) data terbesar dan terkecil adalah 58,33. Ini menunjukkan sebaran data yang menyebar tidak merata, yang ditunjukkan dengan standar deviasi yang cukup besar yaitu 12,79 , yang mengindikasikan pengetahuan yang tidak sama dari setiap peserta pelatihan. Adapun nilai rata-rata peserta pelatihan adalah 35,83. Jika ingin diketahui ada berapa orang yang memperoleh nilai tinggi dan rendah dari peserta pelatihan disajikan dalam gambar 1 di bawah ini :

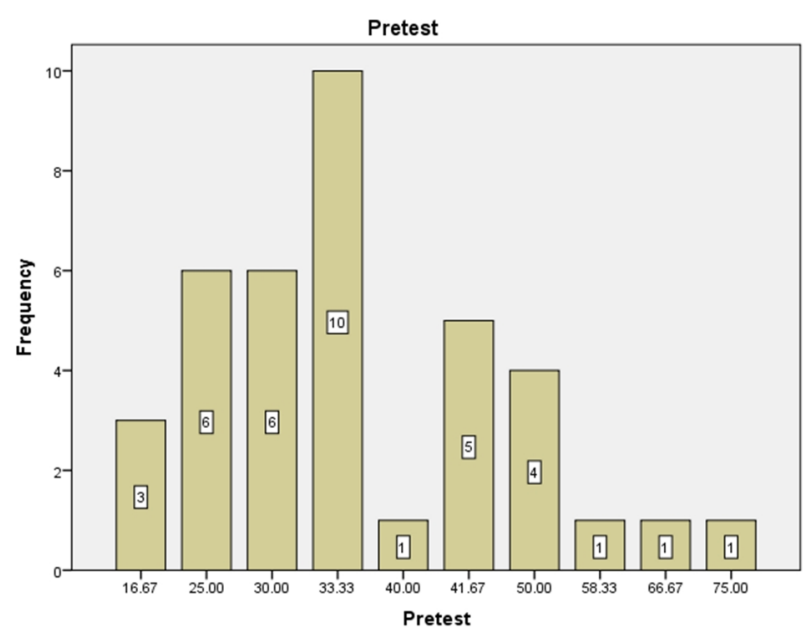

Gambar 1. Jumlah Perolehan Nilai Pre Test Peserta Pelatihan 
Yang memperoleh nilai 16,67 adalah mereka yang hanya mengetahui Microsoft Excel saja, ada 7,9\%, sedangkan yang paling tinggi memperoleh nilai 75 hanya ada satu orang atau 2,6\%, yaitu mereka yang mengetahui Microsoft Excel, fungsi pada Microsoft Excel, 5 formula yang difasilitasi oleh exel, fungsi mailing pada Microsoft Word, namun belum mengetahui tentang langkah-langkah yang dilakukan dalam penggunaan Mailings, dan Prezi. Dan paling banyak memperoleh nilai 33,33 sebesar 26,3\% atau yang mengetahui Microsoft Excel, 3 tipe data dalam Microsoft Exel.

Setelah mengikuti pelatihan teori dan praktek selama dua hari, peserta pelatihan ditest kembali pengetahuannya tentang hal yang sama, kemudian dicatat perolehan nilainya sebagai berikut :

Tabel 2. Nilai Post test Peserta Pelatihan

\begin{tabular}{|c|c|c|}
\hline & Post test \\
\hline \multirow[t]{2}{*}{$\mathrm{N}$} & Valid & 38 \\
\hline & Missing & 0 \\
\hline \multicolumn{2}{|c|}{ Mean } & 71.6229 \\
\hline \multicolumn{2}{|c|}{ Median } & 75.0000 \\
\hline \multicolumn{2}{|c|}{ Mode } & 75.00 \\
\hline \multicolumn{2}{|c|}{ Std. Deviation } & 14.96036 \\
\hline \multicolumn{2}{|c|}{ Variance } & 223.812 \\
\hline \multicolumn{2}{|c|}{ Range } & 51.67 \\
\hline \multicolumn{2}{|c|}{ Minimum } & 40.00 \\
\hline \multicolumn{2}{|c|}{ Maximum } & 91.67 \\
\hline
\end{tabular}

Perolehan nilai Post test dari 38 peserta pelatihan rata-rata 71,62, dengan nilai terendah 40 dan nilai tertinggi 91,67. Dengan demikian range nya menjadi lebih kecil dibanding pretest yaitu 51,67, sementara simpangan bakunya 14,96. Ini mengindikasikan peserta mengalami kenaikan pengetahuan secara keseluruhan, namun sebarannya masih lebar karena ada yang meningkat pengetahuannya cukup tajam, tapi ada yang meningkatnya tidak begitu besar. Untuk mengetahui berapa orang yang memperoleh nilai tinggi dan nilai rendah akan di sajikan dalam gambar 2 sebagai berikut :

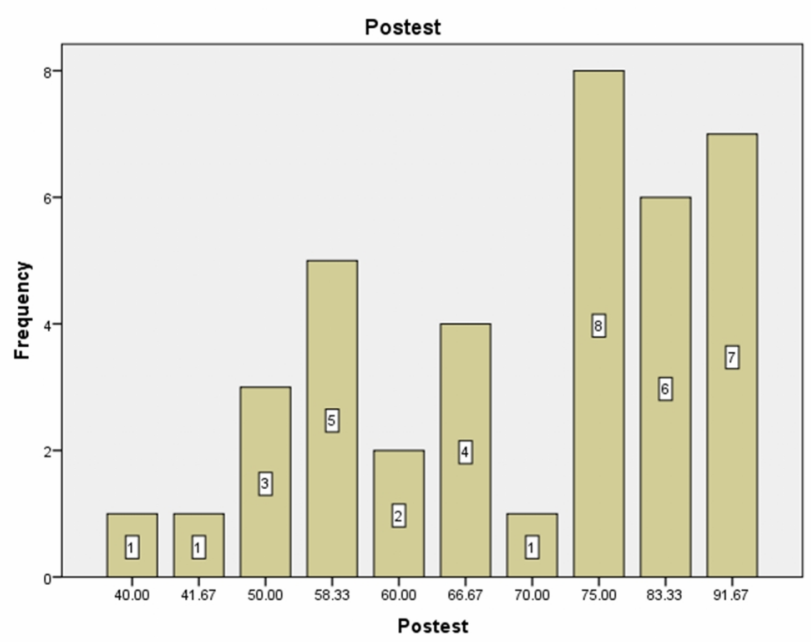

\section{Gambar 2. Jumlah Perolehan Nilai Post test}

Dari gambar 2 terlihat yang memperoleh nilai terendah ada 1 orang yaitu nilainya 40, jika kita melihat kepada hasil test yang mendapat nilai 40, adalah mereka yang sudah mengerti tentang Microsoft Excel sampai fungsi dalam Microsoft Excel, sedangkan yang tertinggi nilainya 91,67 ada 7 orang. Perolehan nilai 91,67 ini, peserta 
sudah paham Microsoft Excel, sampai penggunaan Mailling, namun masih belum mengerti betul tentang software Prezi.

Walaupun terlihat nilai semua peserta naik dari nilai pretest ke nilai post test, namun belum meyakinkan apakah kenaikan nilai itu berarti secara statistik atau dengan kata lain, peningkatan pemahaman akan metode pembelajaran berbasis TIK dari peserta pelatihan itu naik secara berarti. Untuk itu dengan menggunakan hipotesis :

$\mathrm{H}_{0}: \mu_{\mathrm{B}}=0$, nilai pretest dan post test sama, atau tidak ada kenaikan pengetahuan mengenai materi pelatihan.

$\mathrm{H}_{1}: \mu_{\mathrm{B}}>0$, nilai post test lebih besar dari pretest, atau ada kenaikan pengetahuan mengenai materi pelatihan.

Dengan menggunakan software SPSS diperoleh :

\section{Tabel 3. Rata-rata dan Standar Deviasi Pada Pretest dan Post test}

Paired Samples Statistics

\begin{tabular}{|ll|l|r|r|r|}
\hline & & Mean & N & Std. Deviation & Std. Error Mean \\
\hline Pair 1 & Postest & 71.6229 & 38 & 14.96036 & 2.42689 \\
& Pretest & 35.8332 & 38 & 12.79168 & 2.07508 \\
\hline
\end{tabular}

Tabel 4. Statistik Uji Untuk Uji Rata-rata Nilai Postest dan Pretest Paired Samples Test

\begin{tabular}{|c|c|c|c|c|c|c|c|c|}
\hline & \multicolumn{5}{|c|}{ Paired Differences } & \multirow[b]{3}{*}{$\mathrm{t}$} & \multirow[b]{3}{*}{$\mathrm{df}$} & \multirow{3}{*}{$\begin{array}{l}\text { Sig. (2- } \\
\text { tailed) }\end{array}$} \\
\hline & \multirow[b]{2}{*}{ Mean } & \multirow{2}{*}{$\begin{array}{c}\text { Std. } \\
\text { Deviation }\end{array}$} & \multirow{2}{*}{$\begin{array}{c}\text { Std. Error } \\
\text { Mean }\end{array}$} & \multicolumn{2}{|c|}{$\begin{array}{c}95 \% \text { Confidence Interval } \\
\text { of the Difference }\end{array}$} & & & \\
\hline & & & & Lower & Upper & & & \\
\hline $\begin{array}{ll}\text { Pair } & \text { Postest - } \\
1 & \text { Pretest }\end{array}$ & 35.78974 & 17.00042 & 2.75783 & 30.20184 & 41.37764 & 12.977 & 37 & .000 \\
\hline
\end{tabular}

Terlihat pada Tabel 3 nilai rata-rata post test lebih besar dari nilai rata-rata pre test, namun jika dilihat dari standar deviasi nilai pre test lebih kecil dari nilai post test, yang artinya nilai pre test lebih seragam dari nilai post test. Dengan kata lain peserta pelatihan pengetahuannya lebih seragam pada saat pre test, dibanding post test, hal ini terjadi karena ada banyak peserta yang pengetahuannya naik melebihi kelompoknya.

Pada table 4 dapat dilihat rata-rata kenaikan nilai dari pre test ke post test adalah 35,79 dengan standar deviasi 17,0 . Statistik uji untuk menguji Hipotesis di atas nilainya adalah 12,97, dengan nilai Sig 0,00 sehingga $\mathrm{H}_{0}$ ditolak, yang mempunyai arti, nilai rata-rata post test lebih besar dibanding nilai pre test. Dengan demikian Pelatihan yang dilakukan oleh tim PKM dari Unisba, secara berarti dapat menaikkan pengetahuan guru SMA dan sederajat di Kecamatan Cileunyi Kabupaten Bandung.

Para peserta terlihat antusias mengikuti pelatihan. Hal ini dikarenakan meskipun mereka sudah mengenal software komputer sebelumnya, akan tetapi hanya secara umum saja, sehingga banyak fungsi-fungsi dalam Microsoft Excel, Microsoft Word dan teknik presentasi yang tidak dimanfaatkan secara optimal. Dengan adanya pelatihan ini, diharapkan dapat membantu proses pengolahan data oleh para guru dengan lebih efektif.

\section{Kesimpulan}

Hasil yang dicapai dari kegiatan pelatihan adalah peserta mengalami peningkatan pengetahuan tentang Microsoft Excel dan pembelajaran yang menggunakan software Prezi. 
Setelah dilakukan pendampingan semua peserta pelatihan dapat melakukan proses evaluasi hasil belajar siswa menggunakan Microsoft Excel. Namun untuk proses pembelajaran menggunakan software Prezi, hanya 50\% peserta yang berhasil membuat bahan ajar menggunakan software Prezi. Hal ini disebabkan kendala koneksi internet yang kurang mendukung, dan sarana prasarana di sekolah yang kurang memadai.

\section{Daftar pustaka}

Ace Suryadi (9 Maret 2001). Mutu profesi guru. Kompas, hal 9 kol 1-5

Dedi Supriyadi, 1999. Mengangkat Citra dan Martabat Guru.. Yogyakarta: Adicita Karya Nusa.

Edi S, Suwondo (2003). Guru di Indonesia. Jakarta :Dittendik Dirjen dikdasmen Imam Abdul Syukur, (2014). Profesionalisme Guru Dalam Mengimplementasikan

Teknologi Informasi dan Komunikasi di Kabupaten Nganjuk, Jurnal Pendidikan dan Kebudayaan, Vol. 20 Nomor 2.

Moekijat. (1993) Evaluasi pelatihan dalam rangka peningkatan produktivitas. Bandung: Penerbit CV Mandar Maju

Sikula, AE (1976). Personnel administration and human resources management. Santa Barbara: John Wiley \& Sons.

Sujana, 2002, Metoda Statistika, Tarsito-Bandung

Suyanto (3 Pebruari 2001), Guru harus terus mendapat latihan. Kompas hal 9 kolom 14

Tracey, WR (1974) Managing training and development system. New York : Amacom. 2008. Persepsi Guru dan Siswa tentang Manfaat Internet.www.scribd.com/doc/3917314/infrastruktur-internet-dan-persepsi-guru-dan-siswatentang-manfaat-internet. 